\title{
MPs press for investigation of covid related contracts during "sleaze" debate on standards
}

\section{Adrian O’Dowd}

MPs have called for a full investigation into the company that was awarded government contracts related to covid-19 testing equipment worth almost half a billion pounds.

The call was made during a three hour emergency debate held on 8 November about what happened in the House of Commons last week when the government backed plans to review rules on MPs' standards, after the former North Shropshire Conservative MP Owen Paterson was found to have broken lobbying rules by the Commons Standards Committee.

A vote to review the standards system was withdrawn a day later after a backlash from opposition parties and the media.

Paterson, who has now resigned as a MP, was paid for consultancy work by the clinical diagnostics company Randox Laboratories (a role he has since resigned from) and lobbied on the company's behalf.

Last year Randox was awarded two covid-19 testing contracts collectively worth around $£_{500 m}\left(€_{585 \mathrm{~m}}\right.$; $\$ 676 \mathrm{~m}$ ) without the normal competitive tendering process, a decision that the government has said was due to the urgency of the pandemic situation.

\section{Restoring trust}

Leading the debate, Wendy Chamberlain, Liberal Democrat MP for North East Fife, said, "The actions of the government last week have tarnished this house's reputation. I was proud to do the right thing last week by opposing the government and voting to uphold the standards procedure. It is hard to be proud to be a member of parliament when, as a body, we are all tarnished with the government's brush and when in the eyes of the public we are tainted by allegations of sleaze."

Echoing her sentiments, the Labour leader, Keir Starmer, said, "The prime minister must commit to a full and transparent investigation into Randox and the government contracts. What do we know? We know that Randox has been awarded government contracts worth over £6oom, without competition or tender. We know that the former member for North Shropshire lobbied for Randox. We also know that he sat in on a call between Randox and the minister responsible for handling the health contracts.

"Against that backdrop, there is obviously a concern that the use of taxpayers' money, and the effectiveness of our pandemic response may have been influenced by paid advocacy from the former member for North Shropshire. If the prime minister is interested in rooting out corruption, he needs to launch a full investigation. If the prime minister is interested in restoring trust, we need full transparency, with all the relevant correspondence published."

Jess Phillips, Labour MP for Birmingham Yardley, said, "On the point about there being one rule for the people outside this building and different rules for the people inside this building, it has been phenomenal for me this week to see the different contracts that organisations such as Randox have been given without a tender process.

"I speak as somebody who has spent hours and hours of my time working in charities, filling in tender process after tender process for amounts of money like £25 00o."

Kim Johnson, Labour MP for Liverpool Riverside, added, "The member in question was found guilty of breaking cash-for-access rules after he received £10o ooo from two firms that then went on to win hundreds of millions of pounds' worth of covid contracts, despite evidence they were not up to the job.”

\section{World outside politics}

Earlier in the debate Steven Barclay, minister for the Cabinet Office and Chancellor of the Duchy of Lancaster, apologised for what had happened in the Commons the previous week.

"I would like, first, to express my regret and that of my ministerial colleagues over the mistake made last week," he said. "We recognise that there are concerns throughout the house about the standards system and the process by which possible breaches of the code of conduct are investigated. Although sincerely held concerns clearly warrant further attention, the manner in which the government approached last week's debate conflated them with the response to an individual case.”

In a previously issued statement a Randox spokesperson said, "We reiterate that Owen Paterson MP has played no role in securing any Randox contract with DHSC [the Department of Health and Social Care].”

The issue of whether MPs should be allowed to have additional paid roles outside their parliamentary job was also raised during the debate, as some called for all MPs to be banned from having a second job unless this was required to maintain professional accreditations or for public service.

Barclay said, "There is value in MPs having a continued connection with the world outside of politics. Banning all second jobs would have captured some in this house who work, for example, as doctors or nurses and have supported the NHS through the pandemic." 
Alistair Carmichael, Liberal Democrat MP for Orkney and Shetland, added, "On those... members who have outside interests or second incomes, I do not favour an outright ban on second jobs, as that would have the unintended consequence of making more people see this as an occupation from which there would never be any departure."

The absence of the prime minister, Boris Johnson, from the debate was heavily criticised by many opposition MPs but also by some Conservatives such as Mark Harper, MP for Forest of Dean, who said, "Politics is a team game. It's essential to work with your colleagues to deliver anything. As on this occasion ... if the team captain gets it wrong, then I think he should come and apologise to the public and to this house. That's the right thing to do in terms of demonstrating leadership." 